\title{
The Effect of Class Management on Economic Learning Motivation at SMA Negeri 20 Palembang
}

\author{
Erma Yulaini ${ }^{1}$, Diana Widhi Rachmawati ${ }^{*}$, Devi Nur Ahini Oktavia Putri ${ }^{3}$, Nyoman \\ Tri Chayanti ${ }^{4}$ \\ ,1,2,3,4 Universitas PGRI Palembang, Indonesia \\ dianawidhi72@gmail.com*
}

\begin{tabular}{|c|c|}
\hline \multirow{10}{*}{$\begin{array}{l}\text { ARTICLE INFO } \\
\text { Article history: } \\
\text { Received } \\
\text { February 22, } 2021 \\
\text { Revised } \\
\text { March 11, } 2021 \\
\text { Accepted } \\
\text { March 17, } 2021\end{array}$} & ABSTRACT \\
\hline & The purpose of this study was to determine the effect of classroom \\
\hline & Palembang for the $2019 / 2020$ academic year. The research method used \\
\hline & quantitative descriptive method. The sample in the research of class $X$ \\
\hline & amounted to 54 students. In collecting data the re \\
\hline & techniques of documentation and questionnaires. The results showed that \\
\hline & the class management had a significant effect on the economic learning \\
\hline & large effect from the class management of \\
\hline & $31.97 \%$, while the remaining $68.03 \%$ was influenced by other factors. \\
\hline & Therefore, classroom management is needed in the learning process. \\
\hline \multirow[b]{2}{*}{ How to cite } & $\begin{array}{c}\text { Keywords: Classroom Management, Learning Motivation Management } \\
\text { Education }\end{array}$ \\
\hline & $\begin{array}{l}\text { Yuliani, E., Rachmawati, D., Putri, D., \& Chayanti, N. (2021). The Effect of Class } \\
\text { Management on Economic Learning Motivation at SMA Negeri } 20 \text { Palembang. } \\
\text { IJoASER (International Journal on Advanced Science, Education, and Religion), 4(1). } \\
61-75 . \\
\text { https://doi.org/10.33648/ijoaser.v4i1.96 }\end{array}$ \\
\hline \multirow{2}{*}{\multicolumn{2}{|c|}{ Journal Homepage https://ojs.staialfurqan.ac.id/IJoASER/ }} \\
\hline & \\
\hline & $\mathrm{s} / 4.0 /$ \\
\hline
\end{tabular}

\section{INTRODUCTION}

The teaching and learning process is the most important activity to achieve educational and teaching goals. Success in this process will be manifested in the form of changes in behavior and positive student thinking, for example, from behaving less disciplined to behaving in discipline. Meanwhile, these two goals will be achieved if supported by supporting elements in the teaching and learning process. In carrying out teaching and learning activities a teacher must be able to carry out classroom management, namely providing a class atmosphere that is conducive to the joy of learning of students in the teaching and learning process. Good classroom management will also create good teaching and learning interactions.

Classroom management is an effort to create and maintain a conducive classroom condition during the teaching and learning process. According to Djamarah \& Zain (2013) proposed that management or class management activities can be interpreted as the ability of the teacher or homeroom teacher to utilize class potential in the form of providing the widest possible opportunity for each person to carry out creative and directed activities. Hence, the available time and funds can be used 
efficiently to carry out classroom activities related to curriculum and student development

If in the teaching and learning process they are able to manage the class using an appropriate approach, it is expected that students will be more enthusiastic in participating in the teaching and learning proces (Husni, 2020). A teacher must explore the frame of reference for classroom approaches, because in its use he must first ensure that the approach he chooses to handle a classroom management case is the best alternative in accordance with the nature of the problem (Rohani, 2010; Gage, et al., 2017). In this connection, a teacher must be able to choose the right approach according to the situation that occurs in the teaching and learning process. In this study the approaches used are the power approach, the Threat Approach, the Freedom Approach, and the Emotional Atmosphere Approach.

With the existence of approaches in class management, student learning motivation will increase. Motivation to learn is the overall driving force both from within and from outside the student by creating a series of efforts to provide learning conditions such that the learning objectives are achieved. According to Sardiman (2016) "Motivation has two characteristics, namely intrinsic motivation and extrinsic motivation. Intrinsic motivation, namely motives that become active or function, do not need to be stimulated from outside, because in every individual there is already an urge to do something. Meanwhile, extrinsic motivations are active and functional motives due to external stimuli. In this study, researchers used extrinsic motivation. The extrinsic motivation in this study is motivation that comes from the teacher, motivation that comes from family and motivation from other friends. In the teaching and learning process, every student needs concentration for learning, therefore teachers need to create a classroom atmosphere that can arouse student learning motivation in order to direct and manage learning activities effectively and efficiently.

Based on preliminary observations made at SMA Negeri 20 Palembang and interviews with teachers of economic subjects, the classroom management carried out by the teacher was good in the teaching and learning process. This can be seen from the activeness of students in learning. Even though the classroom management is good, there are still students who are less active in learning because during the teaching and learning process students often chat and do not pay attention to the teacher who teaches. Therefore it is very necessary approaches in class management that are appropriate in the teaching and learning process. With these approaches it is expected to motivate students to learn. Furthermore, the learning motivation that arises from students has not yet been seen and students' awareness of learning is very lacking, resulting in low student enthusiasm for learning. Based on the description above, the researchers intend to conduct a study with the title: "The Effect of Classroom Management on Motivation to Study Economics in Public High Schools 20 Palembang Academic Year 2019/2020".

Class management is an activity and teacher skills to make teaching and learning conditions in the classroom well implemented and the objectives of teaching and learning can be achieved (Al Arif \& Amalia, 2016). According to Djamarah \& Zain (2013), "Class management is the skill of teachers to create and maintain optimal learning conditions and restore them if there is a disruption in the teaching and learning process". Meanwhile, according to Arikunto (2013), "They argue that class management is an effort made by the person in charge of teaching and learning activities or helping with the intention of achieving optimal conditions so that learning activities can be carried out as expected". And there is also an opinion according to 
Suryani and Agung (2012) "Class management is the teacher's skill to create and maintain optimal learning conditions and restore them if there is a disruption in the teaching and learning process".

According to Sudirman in Djamarah and Zain (2013) states, "The objectives of class management are essentially contained in educational goals. In general, the purpose of class management is to provide facilities for various student learning activities in the social, emotional, and intellectual environment in the classroom.

These various approaches are as described below:

1. The Approach of Power

2. Threat Approach

3. The Freedom Approach

4. The Prescription Approach

5. Teaching Approach

6. The Behavior Change Approach

7. Emotional Atmosphere and Social Relations Approach

8. Group Process Approach

9. Electrical and Pluralistic Approach

There are several problems in classroom management that a teacher should be aware of, which often occur in teaching and learning activities. According to Made Pidarta in Djamarah and Zain (2013), classroom management problems related to student behavior are:

1. Lack of unity, with the existence of groups, clicks and gender clashes

2. There is no standard of behavior in group work, for example noisy conversations, going here and there and so on.

3. Negative reactions to group members. For example, noisy, hostile, isolating, demeaning stupid groups and so on.

4. The class tolerates the mistakes of its friends, which is to accept and encourage the wrong behavior of students.

5. Easy to react negatively / disturbed, for example when visited by monitors, guests, changing climate and so on.

6. Low morale, hostility, aggressiveness, for example in institutions with less learning tools, lack of money and so on.

7. Not able to adapt to a changing environment, such as additional assignments, new class members, new situations and so on.

Motivation to learn is an impetus and driving force within a person to learn in order to achieve goals, desires, abilities and ideals of learning, both from within himself and from outside himself.

According to Hamalik (2015), Stating that there are several types and characteristics of motivation are as follows:

a. Types of Motivation

There are many kinds of motivation. Parah experts divide the types of motivation according to their respective theories. From the whole motivation theory, three approaches can be proposed to determine the types of motivation, namely: Needs Approach, Functional Approach and Descriptive Approach.

b. Motivational Traits

1. Instrinsic motivation is motivation that is included in learning situations that come from the needs and goals of the students themselves. This motivation is often called "pure motivation", or true motivation, which arises from within students, for example the desire to acquire certain skills, obtain information and understanding, develop 
attitudes to succeed, enjoy life consciously contributing to the group, the desire to accepted by others, and so on.

2. Extrinsic motivation is motivation caused by factors from outside the learning situation, such as: numbers, credits, diplomas, grades, prizes, medals, conflict and competition; the negative ones are sarcasm, ridicule (ridicule), and punishment. Extrinsic motivation is still needed in school, because learning in school does not all attract interest, or according to realizing the needs of students.

According to Djamarah according to Sardiman (2016) "Extrinsic motivation is motives that are active and function because of external stimuli". Extrinsic motivation is said to be important in the teaching and learning process because it is likely that the student's condition is dynamic, changing and there are also other components in the teaching and learning process that are less attractive to students so that extrinsic motivation is needed.

According to De Decee and Grawford (2011), efforts to improve learning outcomes are as follows:

1. Excite students

2. Provide realistic expectations

3. Providing incentives, directing the behavior of students

This research is very important to do because it is to measure how much influence classroom management has on the motivation to learn the economy in SMA Negeri 20 Palembang

SMA Negeri 20 Palembang, so far no research has been carried out, especially with regard to classroom management, so the researcher and the team are interested in doing research in this school

\section{METHOD}

In accordance with the data to be collected in this study, the researchers used data collection techniques. According to Riduwan (2015), documentation is intended to obtain data directly from the research site, including relevant books, regulations, activity reports, photographs, documentary films, research-relevant data.

Based on the above understanding, the researchers used documentation techniques to obtain data on the number of students, the number of teachers and the state of the Air Kumbang 1 Public High School in the 2016/2017 academic year. According to Riduwan (2015), the questionnaire is a list of questions that are given to other people who are willing to respond (respondents) according to user requests. The purpose of distributing questionnaires is to find complete information about a problem and respondents without feeling worried if the respondent gives an

answer that does not match the reality in filling out the questionnaire, while according to Sugiono (2016) "Questionnaire is an information collection technique that allows analysis to study attitudes -the attitudes, beliefs, behavior and characteristics of some of the main people in the organization that could be affected by the proposed system or the existing system.

From some of the opinions above, the questionnaire in this study was used to determine how much classroom management is on student learning motivation in economic subjects. The main material is to distinguish commercial banks and central banks. In this study, the questionnaire model used was a closed model, namely the answer alternatives model that had been provided. In this study using a measurement scale, namely the Likert scale. According to Arikunto (2014), "Validity is a measure that shows the levels of validity or validity of an instrument. An instrument that is valid or 
valid has high validity. On the other hand, less valid instruments have low vaidity ". Meanwhile, according to Sugiyono (2004), "if the instrument is said to be valid, it means it shows the measuring instrument used to get the data is valid so that it means that the instrument can be used to measure what should be measured. In this study using the product moment formula with rough numbers Formula :

$$
\mathbf{r x y}=\frac{n(\Sigma X Y)-(\Sigma X) \cdot(\Sigma Y)}{\sqrt{\left(n \Sigma x^{2}-(x)^{2}\right] \cdot\left[n \cdot \Sigma y^{2}-(\Sigma y)^{2}\right]}} \quad \text { (Arikunto, 2014) }
$$

Reliability shows in one sense that an instrument can be trusted enough to be used as a data collection tool because the instrument is good (Arikunto, 2013). The reliability formula used is the alpha formula in this study as follows:

$$
r_{11} \quad\left[\frac{k}{k-1}\right]\left[1-\frac{\sum \sigma_{\mathrm{k}}^{2}}{\sigma_{\mathrm{t}}^{2}}\right]
$$

(Arikunto, 2014)

According to Sugiyono (2016), "Data analysis is an activity after data from all respondents or data sources are collected. The activities in data analysis are: grouping data based on variables and types of respondents, tabulating data based on variables from all respondents, presenting data for each variable studied, performing calculations to test the hypothesis that has been proposed, the steps taken in analyzing the data are:

According to Sugiyono (2016), "Data analysis is an activity after data from all respondents or data sources are collected. The activities in data analysis are: grouping data based on variables and types of respondents, tabulating data based on variables from all respondents, presenting data for each variable studied, performing calculations to test the hypothesis that has been proposed, the steps taken in analyzing the data are:

To analyze the questionnaire data using quantitative descriptive analysis with the following steps

1. Provide a score of alternative answer data chosen by students.

2. After giving a score as above, to measure the results of the distribution of questionnaires to respondents (students) then analyzed descriptively using a frequency distribution that refers to the following formula:

$$
\begin{gathered}
\mathrm{P}=\frac{s}{S M} X 100 \% \\
\mathrm{P}=\text { Percentage } \\
\text { Where: } \mathrm{P}= \\
\text { Percentage } \\
\mathrm{S}=\text { score obtained } \\
\mathrm{Sm}=\text { Maximum } \\
\text { Score } 100 \%=\text { Fixed } \\
\text { numerator }
\end{gathered}
$$$$
\text { (from Haryadi , 2009) }
$$

Data normality test needs to be done to find out whether the analyzed data is normal or not. The steps used are as follows:

a. Distance $/$ range $=$ Largest Value - Smallest Value

b. Interval class length $(\mathrm{i})=($ Range $) /$ (Multiple Classes $)=\mathrm{R} / \mathrm{K}$

c. Calculate the pric $\sigma^{2}$ 


$$
\chi^{2}=\sum \frac{(f \circ-f h)^{2}}{f h} \quad \text { (in Sianipar dan Hidayat, }
$$

2016:113) Information :

$x^{2}=$ data normality

fo $=$ frequency of

observation $\mathrm{fh}=$ expected

frequency

If $\chi_{\text {hit }}^{2}<\chi_{\text {tab }}^{2}$ then the data is normally distributed.

If $\chi_{\text {init }}^{2} \geq \chi_{\text {tab }}^{2}$ then the data is not normally distributed.

After the data has been collected in an effort to prove the hypotheses that have been formulated in this study, a simple linear regression is used as follows:

1). Hypothesis

Ho: $\beta=0$; There is no effect of classroom management on the motivation to study economics in public high schools 20 Palembang for the 2019/2020 academic year

Ha: $\beta \neq 0$; There is the Effect of Classroom Management Management on Learning Motivation in Economics Subjects SMA Negeri 20 Palembang for the 2019/2020 academic year

2). Statistic Test

The test statistic used is the " $\mathrm{t} "$ test 3). Significance Level

The significance level of testing was used $95 \%$ or a 0.05 , with a sample size of 54 students

4). Critical Value

Critical Value for determining the rejection $H_{0}$ region at t a $0,05 / 2 \mathrm{db} ; \mathrm{n}-2$ is $\mathrm{t}$ a $0,05 \mathrm{db} 54-2$ in the table " $\mathrm{t}$ " is 2.021

5). Testing criteria

Accept $\quad t_{\text {hit }} \geq-t_{\text {tab }}=2,021$ atau $t_{\text {hit }} \leq t_{\text {tab }} \quad, 2,021$; reject $H_{a}$

Reject : bila $H_{0} \quad t_{\text {hit }}<-t_{\text {tab }}$ 2,021 atat hit $>t_{\text {tab }}$ 2,021: $\quad H_{a}$

accept

6). Regression calculations

Regression calculations will be obtained from the regression calculation aid table

6.1 the prices of $b$ and $a$ are

$\mathrm{b}=\mathrm{b} \frac{\sum x y}{\Gamma^{2}}$ (Supranto, 2009 in Sianipar and Hidayat, 2016:18)

$\mathrm{a} \overline{\bar{Y}}-\mathrm{b}_{\bar{X}}$ 
IJoASER (International Journal on Advanced Science, Education, and Religion)

\begin{tabular}{|c|c|c|c|c|c|}
\hline \multicolumn{3}{|c|}{ Class Management } & \multicolumn{3}{|c|}{ Student's Motivation to Study } \\
\hline Skor & $\%$ & Criteria & Skor & $\%$ & Criteria \\
\hline 64 & 4 & High & 62 & 82 & High \\
\hline 66 & 7 & Very High & 64 & 84 & High \\
\hline 65 & 6 & Very High & 61 & 80 & High \\
\hline 68 & 9 & Very High & 58 & 76 & High \\
\hline 65 & 6 & Very High & 63 & 83 & High \\
\hline 65 & 6 & Very High & 69 & 91 & Very High \\
\hline 66 & 7 & Very High & 71 & 93 & Very High \\
\hline 64 & 4 & High & 64 & 84 & High \\
\hline 62 & 2 & High & 65 & 86 & High \\
\hline 64 & 4 & High & 60 & 79 & High \\
\hline 62 & 2 & High & 64 & 84 & High \\
\hline 65 & 6 & Very High & 64 & 84 & High \\
\hline 66 & 7 & Very High & 62 & 82 & High \\
\hline 61 & 0 & High & 67 & 88 & Very High \\
\hline 61 & 0 & High & 64 & 84 & High \\
\hline 63 & 3 & High & 61 & 82 & High \\
\hline 63 & 3 & High & 63 & 83 & High \\
\hline 62 & 2 & High & 61 & 80 & High \\
\hline 66 & 7 & Very High & 64 & 84 & High \\
\hline 59 & 8 & High & 54 & 71 & High \\
\hline 58 & 6 & High & 59 & 78 & High \\
\hline 65 & 6 & Very High & 65 & 86 & Very High \\
\hline 63 & 3 & High & 61 & 80 & High \\
\hline 65 & 6 & Very High & 68 & 89 & Very High \\
\hline 64 & 4 & High & 66 & 87 & Very High \\
\hline 67 & 8 & High & 61 & 80 & High \\
\hline 65 & 6 & Very High & 64 & 84 & High \\
\hline 64 & 4 & High & 69 & 91 & Very High \\
\hline 66 & 7 & Very High & 65 & 86 & Very High \\
\hline 68 & 9 & High & 62 & 82 & High \\
\hline 63 & 3 & High & 69 & 91 & Very High \\
\hline 64 & 4 & High & 64 & 84 & High \\
\hline 64 & 4 & High & 67 & 88 & Very High \\
\hline 66 & 7 & Very High & 66 & 87 & Very High \\
\hline 63 & 3 & High & 68 & 89 & Very High \\
\hline 59 & 8 & High & 59 & 78 & High \\
\hline 63 & 3 & High & 67 & 88 & Very High \\
\hline 62 & 2 & High & 61 & 80 & High \\
\hline 69 & 1 & Very High & 61 & 80 & High \\
\hline 62 & 2 & High & 65 & 86 & Very High \\
\hline 61 & 0 & High & 59 & 78 & High \\
\hline 60 & 9 & High & 61 & 80 & High \\
\hline 61 & 0 & High & 62 & 82 & Tinggi \\
\hline 61 & 0 & High & 66 & 87 & Very High \\
\hline 58 & 6 & High & 60 & 79 & High \\
\hline 60 & 9 & High & 63 & 83 & High \\
\hline 63 & 3 & High & 67 & 88 & Very High \\
\hline 67 & 8 & Very High & 62 & 82 & High \\
\hline 67 & 8 & Very High & 64 & 84 & High \\
\hline 57 & 5 & High & 66 & 87 & Very High \\
\hline 64 & 4 & High & 59 & 78 & High \\
\hline 63 & 3 & High & 63 & 83 & High \\
\hline
\end{tabular}




\begin{tabular}{|l|l|l|l|l|l|}
\hline 62 & 2 & High & 62 & 82 & High \\
\hline 64 & 4 & High & 61 & 80 & High \\
\hline
\end{tabular}

6.2 regression equation;

$$
\hat{Y}=a+b X
$$

6.3 standard error of estimating regression results (Se)

$S e^{2}=\frac{\sum y^{2}-b \sum x y}{n-2}$ atau $S e^{2}=\frac{\sum y^{2}-b^{2} \sum x^{2}}{n-2}$ (supranto, 2009 in Sianipar

and Hidayat 2017: 19)

6.4 Standard Error Regression Coefficient (Sb)

$\mathrm{Sb}=\frac{S e}{\sqrt{\Sigma x^{2}}}($ Supranto, In Sianipar and Hidayat 2016: 19)

Consider furqon: $\mathrm{Sb}=\sqrt{\frac{S e}{\sum x^{2}}}$ (Furqon, 2004: 228 in Sianipar and

Hidayat, 2016: 19)

6.5 “ $\mathrm{t}$ " price (“ $\mathrm{t}$ ” count)

$t_{\text {hitung }}=\frac{b}{S b}$ (Supranto, 2009 in Sianipar and Hidayat, 2016:

19) Deference Coefficient (KD)

$\mathrm{Kd}$ is

$r^{2}$ yaitu: $r^{2} \frac{\underline{\underline{b} \Sigma x y}}{\Sigma y^{2}} \hbar^{2} \quad$ (Supranto, 2009 in Sianipar and Hidayat, 2016:

20) $\frac{S_{b^{2}}^{2} \sum x^{2}}{\sum y^{2}}$

The criteria for testing the hypothesis using the " $t$ " test with the significance level used is $95 \%$ or a 0.05 two-party test with the following conditions:

Ho: $\beta=0$; There is no effect of classroom management on learning motivation in economics subjects at SMA Negeri 20 Palembang in the 2019/2020 academic year

Ha: $\beta \neq 0$; There is an Influence of Classroom Management on Learning Motivation in Economics Subjects in SMA Negeri 20 Palembang in the 2019/2020 Academic Year

To test the hypothesis in this study with a significant level of $a=0.05$, the researchers used the following criteria:

if thitung $\leq$ ttabel $a 0.05$ then reject Ho, accept $\mathrm{Ha}$ if rhitung $\geq$ rtabel 0.05 then accept Ho reject Ha

\section{RESULT AND DISCUSSION}

Table 1 : Class Management Comparison Score and Student Learning Motivation

\begin{tabular}{|c|l|l|l|c|l|}
\hline \multicolumn{3}{|c|}{ Class Management } & \multicolumn{3}{c|}{ Student's Motivation to Study } \\
\hline Skor & $\mathbf{0}$ & Criteria & Skor & \% & Criteria \\
\hline 64 & 4 & High & 62 & 82 & High \\
\hline 66 & 7 & Very High & 64 & 84 & High \\
\hline 65 & 6 & Very High & 61 & 80 & High \\
\hline
\end{tabular}




\begin{tabular}{|c|c|c|c|c|c|}
\hline 68 & 9 & Very High & 58 & 76 & High \\
\hline 65 & 6 & Very High & 63 & 83 & Tinggi \\
\hline 65 & 6 & Very High & 69 & 91 & Very High \\
\hline 66 & 7 & Very High & 71 & 93 & Very High \\
\hline 64 & 4 & High & 64 & 84 & High \\
\hline 62 & 2 & High & 65 & 86 & High \\
\hline 64 & 4 & High & 60 & 79 & High \\
\hline 62 & 2 & High & 64 & 84 & High \\
\hline 65 & 6 & Very High & 64 & 84 & High \\
\hline 66 & 7 & Very High & 62 & 82 & High \\
\hline 61 & 0 & High & 67 & 88 & Very High \\
\hline 61 & 0 & High & 64 & 84 & High \\
\hline 63 & 3 & High & 61 & 82 & High \\
\hline 63 & 3 & High & 63 & 83 & High \\
\hline 62 & 2 & High & 61 & 80 & High \\
\hline 66 & 7 & Very High & 64 & 84 & High \\
\hline 59 & 8 & High & 54 & 71 & High \\
\hline 58 & 6 & High & 59 & 78 & High \\
\hline 65 & 6 & Very High & 65 & 86 & Very High \\
\hline 63 & 3 & tinggi & 61 & 80 & High \\
\hline 65 & 6 & Very High & 68 & 89 & Very High \\
\hline 64 & 4 & High & 66 & 87 & Very High \\
\hline 67 & 8 & High & 61 & 80 & High \\
\hline 65 & 6 & Very High & 64 & 84 & High \\
\hline 64 & 4 & High & 69 & 91 & Very High \\
\hline 66 & 7 & Very High & 65 & 86 & Very High \\
\hline 68 & 9 & High & 62 & 82 & High \\
\hline 63 & 3 & High & 69 & 91 & Very High \\
\hline 64 & 4 & High & 64 & 84 & High \\
\hline 64 & 4 & High & 67 & 88 & Very High \\
\hline 66 & 7 & Very High & 66 & 87 & Very High \\
\hline 63 & 3 & High & 68 & 89 & Very High \\
\hline 59 & 8 & High & 59 & 78 & High \\
\hline 63 & 3 & High & 67 & 88 & Very High \\
\hline 62 & 2 & High & 61 & 80 & High \\
\hline 69 & 1 & Very High & 61 & 80 & High \\
\hline 62 & 2 & High & 65 & 86 & Very High \\
\hline 61 & 0 & High & 59 & 78 & High \\
\hline 60 & 9 & High & 61 & 80 & High \\
\hline 61 & 0 & High & 62 & 82 & High \\
\hline 61 & 0 & High & 66 & 87 & Very High \\
\hline 58 & 6 & High & 60 & 79 & High \\
\hline 60 & 9 & High & 63 & 83 & High \\
\hline 63 & 3 & High & 67 & 88 & Very High \\
\hline 67 & 8 & Very High & 62 & 82 & High \\
\hline 67 & 8 & Very High & 64 & 84 & High \\
\hline 57 & 5 & High & 66 & 87 & Very High \\
\hline
\end{tabular}




\begin{tabular}{|l|l|l|l|l|l|}
\hline 64 & 4 & High & 59 & 78 & High \\
\hline 63 & 3 & High & 63 & 83 & High \\
\hline 62 & 2 & High & 62 & 82 & High \\
\hline 64 & 4 & High & 61 & 80 & High \\
\hline
\end{tabular}

Table 2 : Class Management Comparison Score and Student Learning Motivation

\begin{tabular}{|c|c|c|c|c|c|}
\hline \multicolumn{3}{|c|}{ Class Management } & \multicolumn{3}{|c|}{ Student's Motivation to Study } \\
\hline Skor & $\%$ & Criteria & Skor & $\%$ & Criteria \\
\hline 64 & 84 & High & 62 & 82 & High \\
\hline 66 & 87 & Very High & 64 & 84 & High \\
\hline 65 & 86 & Very High & 61 & 80 & High \\
\hline 68 & 89 & Very High & 58 & 76 & High \\
\hline 65 & 86 & Very High & 63 & 83 & High \\
\hline 65 & 86 & Very High & 69 & 91 & Very High \\
\hline 66 & 87 & Very High & 71 & 93 & Very High \\
\hline 64 & 84 & High & 64 & 84 & High \\
\hline 62 & 82 & High & 65 & 86 & High \\
\hline 64 & 84 & High & 60 & 79 & High \\
\hline 62 & 82 & High & 64 & 84 & High \\
\hline 65 & 86 & Very High & 64 & 84 & High \\
\hline 66 & 87 & Very High & 62 & 82 & High \\
\hline 61 & 80 & High & 67 & 88 & Very High \\
\hline 61 & 80 & High & 64 & 84 & High \\
\hline 63 & 83 & High & 61 & 82 & High \\
\hline 63 & 83 & High & 63 & 83 & High \\
\hline 62 & 82 & High & 61 & 80 & High \\
\hline 66 & 87 & Very High & 64 & 84 & High \\
\hline 59 & 78 & High & 54 & 71 & High \\
\hline 58 & 76 & High & 59 & 78 & High \\
\hline 65 & 86 & Very High & 65 & 86 & Very High \\
\hline 63 & 83 & High & 61 & 80 & High \\
\hline 65 & 86 & Very High & 68 & 89 & Very High \\
\hline 64 & 84 & High & 66 & 87 & Very High \\
\hline 67 & 88 & High & 61 & 80 & High \\
\hline 65 & 86 & Very High & 64 & 84 & High \\
\hline 64 & 84 & High & 69 & 91 & Very High \\
\hline 66 & 87 & Very High & 65 & 86 & Very High \\
\hline 68 & 89 & High & 62 & 82 & High \\
\hline 63 & 83 & High & 69 & 91 & Very High \\
\hline 64 & 84 & High & 64 & 84 & High \\
\hline 64 & 84 & High & 67 & 88 & Very High \\
\hline 66 & 87 & Very High & 66 & 87 & Very High \\
\hline 63 & 83 & High & 68 & 89 & Very High \\
\hline 59 & 78 & High & 59 & 78 & High \\
\hline
\end{tabular}




\begin{tabular}{|l|l|l|l|l|l|}
\hline 63 & 83 & High & 67 & 88 & Very High \\
\hline 62 & 82 & High & 61 & 80 & High \\
\hline 69 & 91 & Very High & 61 & 80 & High \\
\hline 62 & 82 & High & 65 & 86 & Very High \\
\hline 61 & 80 & High & 59 & 78 & High \\
\hline 60 & 79 & High & 61 & 80 & High \\
\hline 61 & 80 & High & 62 & 82 & High \\
\hline 61 & 80 & High & 66 & 87 & Very High \\
\hline 58 & 76 & High & 60 & 79 & High \\
\hline 60 & 79 & High & 63 & 83 & High \\
\hline 63 & 83 & High & 67 & 88 & Very High \\
\hline 67 & 88 & Very High & 62 & 82 & High \\
\hline 67 & 88 & Very High & 64 & 84 & High \\
\hline 57 & 75 & High & 66 & 87 & Very High \\
\hline 64 & 84 & High & 59 & 78 & High \\
\hline 63 & 83 & High & 63 & 83 & High \\
\hline 62 & 82 & High & 62 & 82 & High \\
\hline 64 & 84 & High & 61 & 80 & High \\
\hline
\end{tabular}

From the table above, the conclusion is that the average management management is $83.51 \%$ while the student learning average in economics is $83.46 \%$, this means that class management is on the average motivation in the "HIGH" category and student learning motivation in economic subjects. is in the "HIGH" category. So it can be denied that the classroom management that is carried out greatly affects student learning motivation.

From the table above, the conclusion is that the average management management is $83.51 \%$ while the student learning average in economics is $83.46 \%$, this means that class management is on the average motivation in the "HIGH" category and student learning motivation in economic subjects. is in the "HIGH" category. So it can be denied that the classroom management that is carried out greatly affects student learning motivation

From the research data conducted at SMA Negeri 20 Palembang for the 2019/2020 academic year, namely to determine whether or not there is an effect of class management on student learning motivation, in this study the sample was class $X$ which consisted of 2 (two) classes, namely class X. 1, which amounted to 27 students and class X.3 which amounted to 27 students. So the total sample size is 54 students. This study uses documentation and questionnaire data collection techniques.

From the research results, it can be seen that the results of a classroom management questionnaire conducted in class $X$ at SMA Negeri 20 Palembang for the $2019 / 2020$ academic year. From the results of the class management questionnaire is the score of class management in class X1 and X3, then the lowest score of the questionnaire acquisition is 57 and the highest score is 69.Based on the results of the questionnaire on 54 students of class X SMA Negeri 20 Palembang, the answer to the score of class management is average. -average 63.41 or with a percentage of $83.51 \%$ with the provisions of the High score Interpretation criteria. Furthermore, from the results of the percentage management of the indicator class the highest is the power approach in learning with a percentage value of $17.29 \%$ while the lowest is the emotional atmosphere approach and social relations with a percentage value of $13 \%$ 
and the average percentage result of the indicator class management is $63.41 \%$ with the "MEDIUM" category. From the research results, it can be seen that the results of the student learning motivation questionnaire conducted in class $X$ at SMA Negeri 20 Palembang for the 2019/2020 academic year. Learning Motivation for class X1 and X3, then the lowest score obtained for the questionnaire was 54 and the highest was 71 and based on the results of the questionnaire answers to the students' learning motivation score with an average of 63.38 or with a percentage of $83.46 \%$ with the provision of High score interpretation criteria. Furthermore, from the results of the percentage of student learning motivation per indicator, there is the highest percentage of motivation from friends with a percentage value of $23.22 \%$ while the weakest is motivation from parents with a percentage value of $19.98 \%$. As well as the average percentage of the percentage of student learning motivation indicators of $63.38 \%$ with the category "MEDIUM". From the description above it can be concluded that class management carried out during teaching and learning can increase student learning motivation

$X^{2} \quad$ From the results of the calculation of the normality test of class management data, it is known that the price $x^{2}$ hit $=5,292<X^{2}$ tab a $0.05 \mathrm{dk} 6-1=11.070$, then it can be concluded that the data is normally distributed. And the calculation of the normality test of student learning motivation questionnaire data is known Price hit $=$ $7.861722<$ tab a $0.05 \mathrm{dk} \mathrm{6-1}=11.070$, so it can be concluded that the data is normally distributed. Based on the description above, if the data is at a normal level, hypothesis testing can be done using simple linear regression calculations.

Based on the results of the regression equation, namely $=65.44+0.216 \mathrm{X}$, the results obtained using the " $\mathrm{t}$ " test with a confidence level of $0.05 \% \mathrm{db} n-2 / 54-2=82$, then $t_{\text {hit }} 2.995>t_{\text {tab }} 0.05 / 2 \mathrm{db} 52=2.021$; means reject dan accept , then the research hypothesis which says there is a significant effect of class management on student learning motivation is accepted with the influence of class management of $31.97 \%$, while the remaining $68.03 \%$ is influenced by other factors.

From the description above proves that the learning motivation of students who use classroom management increases. Therefore, classroom management can also be used as an alternative in the teaching and learning process in economic subjects. From the results of the research and discussion of the results, it can be seen that a significant influence in the teaching and learning process by using classroom management in the teaching and learning process becomes very good (active) and students become more motivated in the teaching and learning process.

The Main Result of this research is the effect of class management management on economic learning motivation at SMA Negeri 20 Palembang. Based on observations regarding classroom management, it can be seen that the teacher always prepares students before starting learning, the teacher divides attention to students and always admonishes students who make noise when learning is in progress. The instructions and directions given by the teacher are clear, but there are still some students who do not clearly understand what the teacher says so they ask again, during learning when the teacher gives questions to students the teacher always gives praise to students who can answer questions from the teacher. Sometimes teachers make variations in teaching and hold competitions or competitions, and teachers give punishments to students who often disturb and make noise when learning lessons take place, so that the atmosphere in learning remains calm. There are no prizes given to students who do the questions correctly, the teacher also does not distribute study groups and does not 
place wall hangings and the like because these objects are already in the designated place.

Other research Yuliani (2014) also proposed that here is a positive effect between classroom management and student learning motivation. It can be seen where the Effect of Classroom Management is $34.81 \%$. The various activities that are deliberately carried out by the teacher in the teaching and learning process to be able manage the class well and maintain the teaching and learning conditions optimal so that learning objectives are achieved Based on the results of observations by looking at the teacher's immediate state teaching, managing teachers in the classroom is good enough. Other finding proven that there is a significant influence between the influences class management on the learning motivation of fourth grade students at MIS Darul Istiqamah Makassar (Nurhairiah, 2019). It is reflected in the SPSS output based on the table ANOVA. The deviation from linearity is 0.921 in this case the value $0.921>0.05$ which is a significant standard, it can be conclude that $\mathrm{H}_{1}$ accepted which means there is a linear relationship between classroom management variables and student learning motivation. To create passion for student learning, the teacher must change the learning style to be more interesting or the teacher can change the atmosphere of a boring classroom into a fresher class (El-Bishouty, et al., 2019; Rogowsky, et al., 2015). With pleasant class conditions then students can develop their abilities to be more optimal. With thus, effective and pleasant classroom conditions are an indicator success in classroom management (Back, et al., 2016; Dicke, 2015). Furthermore, the research limitation only looks at the influence of class management management on economic learning motivation and its contribution is the contribution of knowledge to the world of education both in schools and colleges. The results of this study providing benefits for the elements involved in increasing student motivation, including for teacher to be used as input in carrying out the teaching and learning process, especially during class management by using various approaches in class management so that students can learn more enthusiastically. For students in order to make it easier for students to understand learning material, especially in economic subjects and through class management, student learning motivation will increase. For school to help improve and develop classroom management methods, it is hoped that it can improve the quality of schools

\section{CONCLUSIONS}

Based on the results of the research that has been done, it can be concluded as follows: The results of the questionnaire for 54 students of class X SMA Negeri 20 Palembang obtained the answer to the class management score with an average of 63.41 or with a percentage of $83.51 \%$ with the provisions of the high score interpretation criteria. Furthermore, the results of a questionnaire to 54 students of class X SMA Negeri 20 Palembang obtained the answer to the student's learning motivation score with an average of 63.38 or with a percentage of $83.46 \%$ with the provisions of the high score interpretation criteria. Based on the results of the regression equation, namely $=65.44+0.216 \mathrm{X}$, the results obtained using the " $\mathrm{t}$ " test with a confidence level of $0.05 \% \mathrm{db} \mathrm{n}-2 / 54-2=82$, then $=2.995>0.05 / 2 \mathrm{db} 52=$ 2.021; means reject dan accept, then the research hypothesis which reads There is a significant effect of Class Management on Student Motivation in Economics Subject at SMA Negeri 1 Air Kumbang in the 2016- 2017 Academic Year with the effect of class management of $31.97 \%$, while the rest is $68,03 \%$ is influenced by other factors. 


\section{ACKNOWLEDGEMENTS}

We would like to express our gratitude to SMA Negeri 20 Palembang for giving permission to conduct one of the Tri Dharma of Higher Education, namely Research for Lecturers and Students with the theme "The Effect Of Class Management Management On Economic Learning Motivation In SMA Negeri 20 Palembang" . We also give our deepest gratitude to the Chancellor of the PGRI Palembang University and his team so that we can carry out Lecturer and Student Research activities. Finally, we would like to express our deepest gratitude to the editorial team of IJoASER (International Journal on Advanced Science, Education, and Religion) AlFurqon Islamic College Makassar Indonesia for giving us the opportunity to publish this article in IJoASER (International Journal on Advanced Science, Education, and Religion) Islamic College of Al-Furqon Makassar Indonesia

\section{AUTHOR CONTRIBUTION STATEMENTS}

EY is the team leader in this research who is in charge of coordinating all the needs prepared in the research of lecturers and students, DWR apart from being journal correspondence, is also the vice chairman who functions to coordinate the preparation of journals, DNAOP and NTC are students who are involved in data collection in the field and assist in data processing in the field.

\section{REFERENCES}

Al Arif, M. N. R., \& Amalia, E. (2016). Teori mikroekonomi: Suatu perbandingan ekonomi Islam dan ekonomi konvensional. Prenada Media. Google Scholar

Arikunto, Suharsimi.2013. Prosedur Penelitian. Jakarta: Rineka Cipta

Back, L. T., Polk, E., Keys, C. B., \& McMahon, S. D. (2016). Classroom management, school staff relations, school climate, and academic achievement: Testing a model with urban high schools. Learning Environments Research, 19(3), 397-410. https:// doi.org/10.1007/s10984-016-9213-x

Tri Handayani, Atik. "Pengaruh Pengelolaan Kelas Terhadap Motivasi Belajar Siswa kelas SD Muhammadiyah 4 Surakarta tahun ajaran 2014/2015". Google Scholar

Djamarah, syaifulBahri.2010. Guru \& Anak Didik dalam Interkasi Edukatif. Jakarta: Rineka Cipta. Google Scholar

Djamarah,Syaiful Bahri \& Aswan Zain.2013. Strategi Belajar-Mengajar. Jakarta: Rineka Cipta

Dicke, T., Elling, J., Schmeck, A., \& Leutner, D. (2015). Reducing reality shock: The effects of classroom management skills training on beginning teachers. Teaching and teacher education, 48, 1-12. https:/ / doi.org/10.1016/j.tate.2015.01.013

El-Bishouty, M. M., Aldraiweesh, A., Alturki, U., Tortorella, R., Yang, J., Chang, T. W., \& Graf, S. (2019). Use of Felder and Silverman learning style model for online course design. Educational Technology Research and Development, 67(1), 161-177. https:// doi.org/10.1007/s11423-018-9634-6

Fauzi, A., \& Fahmi, A. (2020). Pengaruh Pengelolaan Kelas Terhadap Motivasi Belajar Siswa Pada Mata Pelajaran Fiqih (Studi di MTs Al-Fitroh Tangerang). Belajea: Jurnal Pendidikan Islam, 5, 1-69. Google Schoolar

Gage, N. A., Scott, T., Hirn, R., \& MacSuga-Gage, A. S. (2018). The relationship between teachers' implementation of classroom management practices and student behavior in elementary school. Behavioral Disorders, 43(2), 302-315. https:// doi.org/10.1177\%2F0198742917714809

Hamalik,Oemar.2015. Kurikulum dan Pembelajaran. Jakarta : Bumi Aksara. 
Husni, H. (2020). The Effect of Inquiry-based Learning on Religious Subjects Learning Activities: An Experimental Study in High Schools. Jurnal Penelitian Pendidikan Islam, 8(1), 43-54. https://doi.org/10.36667/jppi.v8i1.434

Kristina,Eli.2011. pengaruh Pengelolaan Kelas terhadap hasil belajar geografi siswa di SMANegeri 14 Palembang tahun pelajaran 2010/2011. Palembang: FKIP Universitas PGRI Palembang. Google Scholar

Nurhairiah, I. (2019). Pengaruh Pengelolaan Kelas terhadap Motivasi Belajar siswa kelas IV di MIS Darul istiqamah mamoa raya Makassar (Doctoral dissertation, Universitas Islam Negeri Alauddin Makassar). Google Scholar

Purwanto, Ngalimun. 2012. Prinsip dan teknik evaluasi pengajaran . Bandung: Remaja Kosdakarya. Google Scholar

Riduwan.2015. Belajar Mudah Penelitian. Bandung: Alfabeta Rohani, Ahmad. 2010. Pengelolaan Pengajaran. Jakarta: Rineka Cipta. Google Scholar

Rogowsky, B. A., Calhoun, B. M., \& Tallal, P. (2015). Matching learning style to instructional method: Effects on comprehension. Journal of educational psychology, 107(1), 64. https:// psycnet.apa.org/doi/10.1037/a0037478

Rozalinda. 2014. Ekonomi Islam Teori dan Aplikasinya pada Aktivitas Ekonomi. Jakarta: Raja Grafindo Persada. Google Scholar

Sardiman. 2016. "Interaksi \& Motivasi Belajar Mengajar". Jakarta: PT Raja Grafindo Persada. Google Scholar

Sianipar, Eduar Muharrim Bona., dan Hidayat, Karyadi. 2016. Statistik Analisis Regresi dan Korelasi. Palembang: Noer Fikri. Google Scholar

Sudijono, Anas. 2015. Pengantar Statistik Pendidikan. Jakarta: PT Raja Grafindo Persada Sugiyono. 2016 . Metode Penelitian Pendidikan. Bandung: Alfabeta

Sukirno, Sardono. 2009. Mikro Ekonomi teori Pengantar. Jakarta: Rajawali pers

Suryani, Nunuk dan Leo Agung.2012. Strategi Belajar Mengajar. Yogyakarta: Penerbit Ombak

Sutarno dkk, 2007. Ekonomi Untuk SMA/MA untuk kelas X.Bandung: Yrama Widya

Yuliani, P. (2014). Pengaruh fasilitas belajar, pengelolaan kelas, dan lingkungan keluarga terhadap hasil belajar ekonomi melalui motivasi belajar siswa Kelas XI MA AL-Asror Kota Semarang. Economic Education Analysis Journal, 3(1). Google Scholar

\section{Copyright Holder :}

(C) Yuliani, E., Rachmawati, D., Putri, D., \& Chayanti, N. (2021).

First Publication Right :

(C) IJoASER (International Journal on Advanced Science, Education, and Religion)

This article is under:

CC BY SA 